\title{
Makanan Halal Pada Destinasi Wisata di Nusa Tenggara Barat
}

\author{
${ }^{1}$ Siti Hasanah, ${ }^{2}$ Fitriani Amelia, ${ }^{3}$ Yulias Erwin \\ 1,2,3Universitas Muhammadiyah Mataram, Mataram, Indonesia \\ 1isithasanah@gmail.com, 2 fitrianiamelia@gmail.com, 3yuliaserwin@gmail.com
}

\begin{tabular}{|c|c|}
\hline Article Info & Abstract \\
\hline $\begin{array}{l}\text { Article History } \\
\text { Received: July 12, } 2018 \\
\text { Accepted: September 30, } \\
2018\end{array}$ & \multirow{2}{*}{$\begin{array}{l}\text { The term halal roots from Islamic faith based on the teaching of Quran and } \\
\text { Sunnah. This concept has recently been embraced in the management of } \\
\text { tourism worldwide, including one in Indonesia province of West Nusa } \\
\text { Tenggara. Halal brand attached to food products provided at tourist } \\
\text { destinations tend to be seen from the aspect of ingredients while neglecting } \\
\text { the aspect of processing. In fact, both aspects are inseparable in determining } \\
\text { whether or not a product is halal according to Islamic law or sharia. This } \\
\text { paper aims to explore processing standard of halal food at tourist } \\
\text { destinations in West Nusa Tenggara and compare the processing with that } \\
\text { of Islamic sharia. Comparative method was used to compare the } \\
\text { standardization of halal food available at tourist destinations and the } \\
\text { standardization based on sharia. The findings indicate that practice of halal } \\
\text { tourism in West Nusa Tenggara increases evidenced in the increase of } \\
\text { Moslem travelers visiting this province. However, the processing of food and } \\
\text { beverages need to improve in order to comply with sharia standard as there } \\
\text { are a number of hotels and restaurants in the region that have yet to receive } \\
\text { a halal certificate from the authority, in this case the Indonesian Board of } \\
\text { Islamic Scholars (MUI). }\end{array}$} \\
\hline $\begin{array}{l}\text { Keywords } \\
\text { Makanan Halal } \\
\text { Destinasi Wisata }\end{array}$ & \\
\hline $\begin{array}{l}\text { Support by: } \\
\text { doi) Crossref }\end{array}$ & \\
\hline
\end{tabular}

\section{PENDAHULUAN}

Berwisata sudah menjadi bagian kebutuhan hidup manusia saat ini. Kepenatan yang dilakoni manusia dalam rutinitas kerja membutuhkan tempat yang tenang dan nyaman untuk beristirahat. Pariwisata secara fungsional digunakan manusia untuk menemukan ketenangan, kebahagiaan dalam memaknai kehidupannya. Trend peningkatan kebutuhan manusia untuk berwisata dapat dilihat dari data perkembangan jumlah wisatawan dalam beberapa dekade terakhir. Dinamika pariwisata dunia dalam tiga tahun terakhir dipengaruhi oleh peningkatan jumlah perjalanan antar negara dan pertumbuhan perekonomian terutama di kawasan Asia Pasifik. Total wisatawan dunia pada tahun 2014 mencapai 1.110 juta perjalanan luar negeri atau tumbuh 5\% dibandingkan tahun sebelumnya. Pada tahun 2014 lebih dari 300 juta $(27,1 \%$ dari total wisatawan dunia) melakukan wisata ke Asia dan 96,7 juta di antaranya masuk ke Asia Tenggara. Sementara pada tahun 2015 ditengah situasi global yang tidak kondusif, perjalanan wisatawan dunia masih tumbuh 4,5\%. Jadi, pariwisata tetap mengalami pertumbuhan signifikan.

Makanan dan minuman menjadi bagian yang tak terpisahkan dari kebutuhan wisatawan di daerah-daerah tujuan wisata. Corak dan cita rasa makanan menjadi salah satu magnet wisata, yang biasanya dikemas sedemikian rupa sehingga menjadi daya tarik tersendiri bagi para wisatawan seperti makanan halal. Namun ada kekhawatiran khususnya wisatawan muslim tentang kekhalalan makanan yang tersedia pada destinasi-destinasi wisata. Makanan halal adalah makanan yang boleh atau wajib 
dikonsumsi oleh ummat muslim. Wajib yaitu suatu perbuatan yang apabila dikerjakan mendapat pahala dan bila ditinggalkan mendapat dosa. Bila dilihat dari konteks ini maka perlu dilakukan upaya pemurnian standariasi makanan halal pada destinasi wisata yang sesuai menurut Islam.

Program wisata halal telah lama dikenal dan diterapkan oleh negara-negara yang menjadi icon wisata dunia seperti Jepang, Turki, Malaysia, Thailand, Dubai, Inggris, Korea Selatan, tidak terkecuali Nusa Tenggara Barat, Indonesia. Pemerintah Daerah Nusa Tenggara Barat merupakan provinsi pertama di Indonesia yang serius menerapkan konsep wisata halal, yang ditata secara yuridis melalui Peraturan Daerah (Perda) Nomor 2 Tahun 2016 tentang Parawisata Halal. Tujuan pemerintah NTB membentuk Perda tentang wisata halal adalah untuk memberikan jaminan kepastian hukum kepada para wisatawan muslim berkaitan dengan ketersediaan sarana dan prasana yang sesuai dengan standarisasi halal menurut Islam. Wisata halal adalah kegiatan kunjungan wisata dengan destinasi dan industri pariwisata yang menyiapkan fasilitas produk, pelayanan, dan pengelolaan pariwisata yang memenuhi syariah. Harapan ini nampaknya sulit untuk bisa terealisasi secara maksimal, karena sampai saat ini masih banyak hotel dan restoran di NTB yang belum sepenuhnya menerapkan konsep wisata halal terutama berkaitan dengan pengolahan produk makanan dan minuman.

\section{METODE}

Metodogi yang digunakan dalam tulisan ini adalah metode komparasi atau perbandingan. Dengan metode ini penulis akan membandingkan standadrisasi makanan halal yang ada pada destinasi-destinasi wisata di NTB dengan standarisasi makanan halal sesuai hukum Islam. Melalui metode ini nantinya akan dilihat apakah satndarisasi makanan halal yang ada pada destinasi-destinasi wisata di NTB sudah sesuai dengan standadrisasi hukum Islam atau belum.

\section{HASIL DAN PEMBAHASAN}

\section{Makanan halal pada destinasi wisata di Nusa Tenggara Barat}

Nusa Tenggara Barat atau biasa dikenal dengan sebutan NTB adalah sebuah provinsi berada di bagian timur Indonesa. Wilayah NTB terdiri dari dua buah pulau yaitu Pulau Lombok dan Pulau Sumbawa. NTB diapit oleh dua destinasi wisata dunia yaitu pulau Komodo dibagian timur dan Pulau Bali di bagian barat. Pulau seribu masjid adalah julukan dari pulau lombok yang menjadi salah satu bagian dari provinsi NTB. Julukan ini bermakna bahwa di pulau lombok sangat banyak mesjid sehingga menjadi karakter khas daerah ini yang membedakannya dengan daerah lain. Berdasarkan data terdapat 9000 mesjid besar dan kecil di pulau seluas $5.435 \mathrm{Km} 2$. Alam nan eksotik dengan kultur sosial, agama dan mayoritas masyarakat muslim menjadi daya tarik tersendiri bagi wisatawan terutama wisatawan muslim untuk datang berwisata, ditambah lagi dengan posisi strategis NTB yang berada pada alur lintas dua destinasi wisata dunia ikut menopang peningkatan jumlah wisatawan ke NTB, khususnya wisatawan muslim. Data yang diperoleh bahwa jumlah wisatawan muslim yang datang berkunjung ke NTB pada tahun 2016 sebanyak 6000 orang.

Geliat peningkatan kunjungan wisata muslim ke NTB menuntut para pengelolah wisata untuk dapat menyediakan sarana dan prasarana sesuai standarisasi syariah. Adapun kriteria umum pariwisata syariah ialah; Pertama, memiliki orientasi kepada kemaslahatan umum. Kedua, memiliki orientasi pencerahan, penyegaran, dan ketenangan. Ketiga, menghindari kemusyrikan dan khurafat. Keempat, bebas dari 
maksiat. Kelima, menjaga keamanan dan kenyamanan. Keenam, menjaga kelestarian lingkungan. Ketujuh, menghormati nilai-nilai sosial budaya dan kearifan lokal. Makanan halal merupakan salah satu kebutuhan mendasar wisatawan muslim, karena makanan merupakan kebutuhan primer penunjang hidup manusia. Secara etimologi makan berarti memasukkan melalui mulut, sedangkan makanan adalah segala sesuatu yang dikonsumsi oleh manusia berupa makanan pokok maupun makanan lainnya. Makanan dalam ensiklopedi hukum Islam ialah segala sesuatu yang boleh dimakan oleh manusia atau sesuatu yang dapat menghilangkan lapar. Makanan yang boleh dimakan oleh orang Islam adalah makanan halal, sehingga ketersediaan makanan halal pada destinasi-destinasi wisata penting untuk dijamin kekhalalannya sesuai standarisasi Islam.

Standadrisasi makanan halal pada destinasi-destinasi wisata di NTB bermuara pada ketentuan Al-Qur,an, yang memuat secara tegas tentang jenis-jenis makanan yang diharamkan. Surat Al Maidah ayat 3 : Diharamkan bagimu memakan bangkai, darah, daging babi, (daging hewan yang disembelih atas nama selain Allah, yang tercekik, yang dipukul, yang jatuh ditanduk dan yang diterkam binatang buas, kecuali yang sempat kamu sembelih (sebelum habis nyawahnya) dan yang disembelih atas nama berhala dan (diharamkan juga). Standarisasi makanan halal dalam Islam bukan hanya dari aspek bahan semata, melainkan bersifat menyeluruh mulai, dari bahannya, cara memperolehnya, proses pengolahannya, karena makanan halalpun menjadi tidak halal apabila berdampak kepada hal-hal tertentu seperti mabuk. Dalam Al Qur'an Surat Annhal ayat 67 : Dan dari buah kurma dan anggur kamu buat minuman yang memabukkan dan rizki yang baik sesungguhnya yang demikian itu benar-benar terdapat tanda-tanda (kebesaran Allah) bagi orang-orang yang memikirkan. Standarisasi halal dalam makanan dan minuman meliputi: halal secara zatnya, halal cara memprosesnya, halal cara memperolehnya.

Kriteia makanan haram di atas menunjukkan bahwa makanan-makanan selain yang disebutkan tersebut hukumnya halal dari aspek bahannya. Namun makanan yang bahannya halal bisa menjadi haram apabila diolah dengan cara-cara yang tidak sesuai dengan standarisasi Islam. Untuk menentukan standarisasi halal dilakukan oleh lembaga tertentu yaitu DSN MUI. Standadrisasi inilah yang dijadikan acuan dalam menentukan standar kekhalalan makanan pada destinasi wisata di NTB. Ketentuan ini diatur dalam Pasal 12 Perda No 2 Tahun 2016 yang mengatakan bahwa Industri pariwisata halal adalah usaha-usaha wisata yang menjual jasa dan produk kepariwisataan yang berpatokan pada prinsip-prinsip syari'ah sebagaimana yang ditetapkan oleh DSN-MUI (Dewan Syariah Nasional Majelis Ulama Indonesia). Standarisasi makanan dan minuman halal menurut Islam diatur dalam Fatwa MUI Nomor 4 Tahun 2003 tentang Fatwa Halal.

Fatwa Nomor 4 Tahun 2003 terdiri dari tujuh bagian. Kriteria minuman yang halal menurut standarisasi MUI adalah setiap minuman atau makanan yang tidak memabukkan. Minuman/khmar adalah setiap yang memabukkan baik berupa minuman, makanan maupun lainnya hukumnya adalah haram. Selain makanan dan minuman yang memabokkan bahan tambahan makanan seperti Ethanol, Fusel oil, Ragi, dan Cuka atau senyawa murni yang bukan berasal dari khamr adalah halal. Senyawa ini akan menjadi mubah apabila dalam hasil produk akhirnya tidak terdeteksi, dan haram apabila dalam hasil produk akhirnya masih terdeteksi. Standarisasi halal dalam Islam tidak hanya dalam kekhalalan bahannya, melainkan juga proses pengolahan bahan seperti dalam hal pemotongan hewan. Hewan yang halal dagingnya adalah hewan yang disembelih oleh orang yang beragama Islam dan akil baligh yang dilakukan dengan cara: a) membaca "basmalah" saat menyembelih; b) menggunakan alat potong yang 
tajam; c) memotong sekaligus sampai putus saluran pernafasan/ tenggorokan (hulqum), saluran makanan (mari'), dan kedua urat nadi (wadajain); d) pada saat pemotongan, hewan yang dipotong masih hidup. Pemingsanan hewan (stunning) hukumnya boleh dengan syarat: tidak menyakiti hewan yang bersangkutan dan sesudah di-stunning statusnya masih hidup (hayat mustaqirrah), sedangkan pemingsanan secara mekanik, dengan listrik, secara kimiawi ataupun cara lain yang dianggap menyakiti hewan, hukumnya tidak boleh.

Masalah penggunaan nama bahan makanan dan minuman juga memiliki standar dan kririteria menurut Fatwa MUI. Menggunakan nama dan/atau simbol-simbol makanan/minuman yang mengarah kepada kekufuran dan kebatilan, mengarah kepada nama-nama benda/binatang yang diharamkan, kecuali yang telah mentradisi ('urf) dan dipastikan tidak mengandung unsur-unsur yang diharamkan, makanan/minuman yang menimbukan rasa/aroma (flavour) benda-benda atau binatang yang diharamkan, seperti mie instan rasa babi, bacon flavour, dan makanan/minuman yang menggunakan nama-nama makanan/minuman yang diharamkan hukumnya haram. Sedangkan penggunaan media pertumbuhan/mikroba hukumnya halal bila berasal dari media pertumbuhan yang suci dan haram bila tumbuh dan berasal dari media pertumbuhan yang najis dan haram. Produk mikrobial yang langsung dikonsumsi yang menggunakan bahan-bahan yang haram dan najis dalam media pertumbuhannya baik pada skala penyegaran, skala pilot plant, dan tahap produksi hukumnya haram. Produk mikrobial yang digunakan untuk membantu proses memproduksi produk lain yang langsung dikonsumsi dan menggunakan bahan-bahan haram dan najis dalam media pertumbuhannya, hukumnya haram. Produk konsumsi yang menggunakan produk mikrobial harus ditelusuri kekhalalannya sampai pada tahap proses penyegaran mikroba.

Selain bahan makanan haram yang secara jelas diatur dalam Al Qur.an seperti bangkai, darah, daging babi, (daging hewan yang disembelih atas nama selain Allah, yang tercekik, yang dipukul, yang jatuh ditanduk dan yang diterkam binatang buas terdapat juga bahan makanan lain yang di haramkan seperti kodok. Dasar pertimbangan yang menjadi alasan diharamkannya kodok adalah karena faktor lingkungan. Nabi shallallahu alaihi wasallam melarang membunuh kodok. Jadi, haram membunuh dan memakan kodok. Bagian terakhir Fatwa MUI Nomor 4 tahun 2003 mengatur tentang syarat mencuci bekas anjing dan babi. Membersikan bekas babi dan anjing dilakukan dengan cara di-sertu (dicuci dengan air 7 x yang salah satunya dengan tanah/debu atau penggantinya yang memiliki daya pembersih yang sama), dan suatu peralatan tidak boleh digunakan bergantian antara produk babi dan non babi meskipun sudah melalui proses pencucian.

Untuk memperjelas status atau kekhalalan makanan dan minuman sesuai standar hukum Islam dilakukan melalui tahapan: 1) penetapan kekhalalan produk dilakukan oleh MUI, 2) penetapan kekhalalan produk sebagaimana dimaksud pada ayat 1 dilakukan dalam sidang fatwa halal, 3) Sidang Fatwa halal MUI sebagaimana dimaksud pada ayat 2 mengikutsertakan fakar, unsur kementrian dan lembaga, dan/atau instansi terkait. 4) sidang fatwa halal sebagaimana dimaksud pada ayat 3 memutuskan kekhalalan produk paling lama 30 hari kerja sejak MUI menerima hasil pemeriksaan, dan/atau pengujian produk dari BPJPH. 5) keputusan penetapan halal sebagaimana dimaksud pada ayat 4 di tandatangani oleh MUI. 6) Keputusan penetapan halal produk sebagaimana dimaksud pada ayat 5 disampaikan kepada BPJPH untuk menjadi dasar penerbitan sertifikat halal.

Dari standarisasi di atas dapat disimpulkan bahwa makanan dan minuman dikatakan halal harus memenuhi beberapa standar: a) bukan terdiri atau mengandung 
bahan-bahan dari binatang yang bagi orang Islam dilarang menurut hukum syarak untuk memakannya atau tidak disembelih menurut hukum syariah, b) tidak mengandung bahan-bahan yang hukumnya najis menurut hukum syariah, c) tidak disiapkan atau diproses menggunakan bahan-bahan atau peralatan yang tidak terbebas dari najis menurut hukum syariah, d) dalam proses pengadaan, pengolahan dan penyimpanannya tidak bersentuhan atau berdekatan dengan bahan-bahan yang tidak memenuhi point $\mathrm{a}$, b dan $\mathrm{c}$ atau bahan-bahan yang hukumnya najis sesuai hukum syarak. Yusuf Qardhawi menggariskan beberapa prinsip dalam penentuan haram dan halal yaitu: a) asal segala sesuatu adalah harus (mubah), b) penentuan halal dan haram adalah hal Allah, c) mengharamkan yang halal dan menghalalkan yang haram sama dengan syirik, d) perkara yang halal menafikkan keperluan kepada yang haram. e) wasilah atau helah untuk melakukan yang haram adalah haram, e) niat yang baik Tidak dapat menghalalkan yang haram. f) menghindari syubhat agar tidak jatuh kedalam yang haram. g) haram dan halal itu bersifat universal. g) keadaan darurat membolehkan yang haram.

Dalam praktek konsep wisata halal yang diterapkan pada destinasi wisata di NTB belum sepenuhnya menerapkan standarisasi halal menurut MUI, karena sebagian besar hotel dan restoran di NTB baru mendapat sertifikat halal MUI kriteria halal 1. Data Dinas Budaya dan Parawisata NTB tahun 2014 menyebutkan terdapat 891 hotel dengan total 9,015 kamar, dan pada tahun yang sama jumlah rumah makan yang termasuk kelompok restoran adalah 1379 unit. Pada Tahun 2015 MUI Provinsi NTB telah menerbitkan 170 sertifikasi untuk hotel, restoran, katering, dan produk olahan. Tahun 2016 MUI NTB menargetkan 500 sertifikat halal. Hampir 99 \% hotel dilombok kini sudah memenuhi katagori halal 1 dengan kelengkapan fasilitas ibadah, mulai dari tempat wudhu, mushola, hingga pernyediaan sajadah.

Kriteria halal pada hotel dan restoran di NTB diklasifikasi dalam tiga kriteria yaitu kriteria halal 1(satu), halal 2(dua), dan kriteria mutlak. Kriteria halal 1(satu) adalah penggolongan untuk usaha hotel syariah yang dinilai memenuhi seluruh kriteria hotel syariah yang diperlukan untuk melayani kebutuhan minimal wisatawan muslim. Fasilitas tersebut seperti sajadah, Al Qur,an, sarung, mukenah, mushollah dan arah kiblat. Kriteria halal 2(dua) adalah penggolongan untuk usaha hotel syariah yang dinilai memenuhi seluruh kriteria hotel syariah yang diperlukan untuk melayani kebutuhan moderat wisatawan muslim. Kriteria mutlak adalah ketentuan dan persyaratan minimal tentang produk, pelayanan, dan pengelolaan yang wajib dipenuhi dan dilaksanakan oleh pengusaha hotel sehingga dapat diakui sebagai usaha hotel syariah dan memperoleh sertifikat usaha hotel syariah. Sertifikat halal adalah bukti yang diberikan oleh DSN MUI pada usaha hotel yang telah memenuhi penilaian kesesuaian standarisasi halal syariah. Standar syariah yang harus disediakan oleh destinasi wisata di NTB juga mengacu pada peraturan Gubernur NTB Nomor 51 Tahun 2015. Dalam ketentuan Pasal 5 ayat (1) Peraturan Gubernur Nomor 51 Tahun 2015 dijelaskan bahwa dalam destinasi wisata halal disediakan: a) fasilitas ibadah yang layak dan suci, b) makanan dan minuman halal, c) pertunjukan seni dan budaya serta atraksi yang tidak bertentangan dengan kriteria umum parawisata syariah, d) kebersihan sanitasi dan lingkungan. Pasal 7 ayat (3) dalam hal belum ada sertifikat halal setiap penyedia makanan dan minuman harus: a) mencantumkan tulisan halal/non halal pada setiap jenis makanan dan minuman, b) terjaga lingkungan yang sehat dan bersih.

Kriteria halal 1 yang telah diterapkan pada sebagian besar hotel dan restoran di NTB sebenarnya belum memberikan jaminan kepada wisatawan muslim terhadap kekhalalan makanan dan minuman yang di konsumsinya, karena hotel dan restoran di NTB sebagaian besar baru terdaftar pada kriteria halal 1 yang hanya memfasilitasi 
ketersediaan sarana dan prasarana ibadah, padahal standarisasi makanan justru yang paling penting. Makanan menjadi penentu kualitas dan keabsahan ibadah diterima atau tidak ibadahnya oleh ALLah SWT, karena ada korelasi antara ibadah dan makanan yang masuk kedalam tubuh manusia menurut pandangan Islam. Dalam sebuah hadis, dari Abu Hurairah ra, Rasulullah saw bersabda yang artinya, " Sesungguhnya Allah Ta'ala itu baik dan tidak menerima kecuali yang baik, dan sesungguhnya Allah Ta'ala telah memerintahkan kaum mukmin dengan apa yang telah Ia perintahkan kepada para rasul. maka Allah SWT berfirman yang artinya, "Wahai para rasul makanlah dari yang baik dan beramal salehlah". Allah berfirman yang artinya." Hai orang-orang yang beriman, makanlah di antara rezki yang baik-baik yang Kami berikan kepadamu dan bersyukurlah kepada Allah, jika benar-benar kepada-Nya saja kamu menyembah." (Qs. Al-Baqarah:172). Ayat ini menjadi dasar rujukan wajib bagi orang muslim untuk mengkonsumsi yang halal. Wajib artinya bila dilakukan mendapat pahala dan bila dilanggar ganjarannya dosa, karena menjaga kualitas makanan yang masuk kedalam tubuh menjadi bagian dari akidah dan wujud ketaatan ummat muslim kepada Allah SWT, sehingga setiap makanan yang dikonsumsi harus jelas kekhalalannya. Ketentuan halal dan haram terintegrasi ke dalam suatu kerangka keimanan (akidah), syariat, dan akhlak. Dari aspek syariah, bagi kaum Muslim, syariat menuntut ketaatan dan merupakan fokus keimanan.

Data di atas menunjukkan bahwa hotel dan restoran pada destinasi wisata di NTB belum memenuhi standarisasi halal dalam pengolahan produk makanan, karena pengolahan makanan halal masih diolah pada dapur yang sama dengan makanan haram. Pengolahan yang dilakukan pada tempat yang sama dan menggunakan alat yang sama akan mencemari zat makanan halal sehingga menjadi haram. Dalam Fatwa MUI Nomor 4 Tahun 2003 bagian ketuju poin 3 tentang masalah mencuci bekas babi dan anjing harus dilakukan dengan cara a. Caranya di-sertu (dicuci dengan air $7 \mathrm{x}$ yang salah satunya dengan tanah/debu atau penggantinya yang memiliki daya pembersih yang sama). b. Suatu peralatan tidak boleh digunakan bergantian antara produk babi dan non babi meskipun sudah melalui proses pencucian.

\section{Makanan Halal menurut Hukum Islam}

Dalam Bahasa Arab makanan berasal dari kata at-ta'am ( الطعام ) dan jamaknya Al atimah (الأطعمة) yang artinya makan-makanan. Bagi ummat Islam tidak semua makanan boleh dimakan, karena dalam Islam ada standadrisasi atau kriteria makanan yang boleh (halal) dan tidak boleh (haram) dimakan. Kata halal berasal dari Bahasa Arab membolehkan, memecahkan, membebaskan dan lainnya. Secara terminologi atau istilah kata halal diartikan sebagai segala sesuatu yang apabila dilakukan tidak mendapat hukuman atau dosa dengan kata lain apa halal dapat diartikan sebagai perbuatan atau segala sesuatu yang diperbolehkan dalam syariah agama Islam. Muhammad ibn 'Ali alSyawkânî (1759-1834 H) berpendapat, dinyatakan halal karena telah terurainya simpul tali atau ikatan larangan yang mencegah. Dari kalangan ulama kontemporer, seperti Yusuf al-Qaradhawî, mendifinisikan halal sebagai sesuatu yang dengannya terurailah buhul yang membahayakan, dan Allah memperbolehkan untuk dikerjakan. Abd alRahmân ibn Nâshir ibn al-Sa'dî' ketika mendifinisikan kata "halâl" menyorotinya kepada bagaimana memperolehnya, bukan dengan cara ghashab, mencuri, dan bukan sebagai hasil muamalah yang haram atau berbentuk haram. Halal berarti sesuatu yang diizinkan dan biasanya digunakan untuk pengertian sah. Konsep halal dalam Islam memiliki motif yang sangat spesifik seperti untuk melestarikan kemurnian agama, untuk menjaga mentalitas Islam, untuk mempertahankan hidup, dan untuk menjaga harga diri serta integritas. 
Menurut pandangan Islam pada dasarnya semua makanan adalah halal kecuali yang disebutkan secara jelas pelarangannya dalam Al Qur,an. Dalam surat Al-Baqarah ayat 29 Allah SWT berfirman yang artinya: Dialah Allah yang menjadikan segala yang ada dibumi untuk kamu dan Dia berkehendak (menciptakan) langit lalu dijadikan-Nya tujuh langit. Dan Dia Maha Mengetahui segala sesuatu. Walaupun semua makanan pada dasarnya halal namun ada pembatasan tentang larangan mengkonsumsi yang haram. Dalam Al-Qur,an surat Al Maidah 88 Allah berfirman yang artinya: dan makanlah makanan yang halal lagi baik dari apa yang telah Allah rezeqikan kepadamu dan bertaqwalah kepada Allah dan kamu beriman kepadaNya. Dalam surat An Nahl 114 Allah SWT berfirman yang artinya Maka makanlah yang halal lagi baik dari rezeqi yang diberikan Allah kepadamu, dan syukurilah nikmat Allah, jika kamu hanya menyembah kepadaNya. Pelarangan tentang perintah Allah untuk memakan makanan yang haram diatur secara khusus tentang jenis-jenisnya. Dalam surah Al-Baqarah 173 Allah berfirman yang artinya: sesungguhnya Allah yang mengharamkan bagimu bangkai, darah, daging babi, dan binatang yang (ketika disembelih) disebut (nama) selain Allah. Tetapi barang siapa dalam keadaan terpaksa (memakannya) sedangkan dia tidak menginginkannya dan tidak (pula) melampaui batas, maka tidak ada dosa baginya sesungguhnya Allah Maha Pengampun lagi Maha Penyayang.

Dalam ayat-ayat ini kata "halal" menjadi dasar perintah mengkonsumsi makanan dan minuman yang halal dan thayyib. Al Qur'an Surat Al Baqarah ayat 168 yang artinya: Wahai sekalian manusia, makanlah yang halal lagi baik dari apa yang terdapat di bumi, dan janganlah kamu mengikuti langkah-langkah syaitan karena sesungguhnya syaitan itu adalah musuh yang nyata bagimu. Al Qur'an Surat Al Mukminun ayat 52 yang artinya: Hai rasul-rasul, makanlah dari makanan-makanan yang baik-baik dan kerjakanlah amal yang sholeh. Dalam Al Qur,an pengaturan tentang makanan halal tidak hanya diatur secara umum, melainkan diatur pula secara terperinci tentang kriteria makanan yang boleh dikonsumsi oleh Ummat Islam.

Kriteria makanan haram dalam Islam meliputi hal-hal berikut: Pertama, bangkai (sesuai dengan Alquran surah al-Mâ'idah ayat 3) yang artinya diharamkan bagimu (memakan) bangkai, darah, daging babi, (daging hewan) yang disembelih atas nama selain Allah, yang tercekik, yang terpukul, yang jatuh, yang ditanduk, dan diterkam binatang buas, kecuali yang sempat kamu menyembelihnya, dan diharamkan bagimu yang disembelih untuk berhala. Dan di haramkan juga mengundi nasib dengan anak panah (mengundi nasib dengan anak panah itu adalah kefasikan. Pada hari ini orangorang kafir telah putus asa untuk mengalahkan agamamu, sebab itu janganlah kamu takut kepada mereka dan takutlah kepada-Ku. Pada hari ini telah Kusempurnakan agamamu, dan telah Kucukupkan nikmat-Ku kepadamu, dan telah Ku ridhoi Islam itu menjadi agamamu. Maka barang siapa karena kelaparan tanpa sengaja berbuat dosa, sesungguhnya Allah Maha Pengampun lagi Maha Penyayang. Al-Baqarah 172 yang artinya hai orang-orang yang beriman, makanlah diantara rezeqi yang baik-baik yang Kami berikan kepadamu dan bersyukurlah kepada Allah. Al-Baqarah 173 yang artinya: sesungguhnya Allah hanya mengharamkan bagimu bangkai, darah, daging babi, dan binatang ketika disembelih disebut nama selain Allah. Tetapi barang siapa yang dalam keadaan terpaksa (memakannya) sedang dia tidak menginginkannya dan tidak pula melampaui batas, maka tidak ada dosa baginya. Sesungguhnya Allah Maha Pengampun Lagi Maha Penyayang. Imam al-Syawkânî mendefinisikan bangkai sebagai binatang yang mati dengan sedirinya, atau dengan kata lain, kematiannya tidak disebabkan karena perbuatan manusia, dengan sengaja disembelih atau karena diburu. Binatang yang kematiannya tanpa penyembelihan secara syariat. Jadi bangkai adalah hewan yang mati dengan sendirinya atau hewan yang kematiannya tanpa disembelih secara syar'i. 
Dikecualikan dari bangkai dua hal, yaitu bangkai belalang dan bangkai ikan laut berdasarkan Hadis yang bersumber dari Ibn Amr.

Kriteria kedua adalah darah. Ayat-ayat Al-Quran yang menetapkan keharaman darah adalah al-Baqarah 172-173, al-Mâ'idah ayat 3. Ketiga, babi. Dasar yang mengharamkan daging babi adalah Alquran surah al-Baqarah 173 dan al-Mâ'idah ayat 3. Dalam Ahkâm al-Qur'ân, al-Jashshâsh menyatakan ayat-ayat tersebut secara jelas menegaskan keharaman daging babi. Keempat, penyembelihan untuk selain Allah. Dasar yang mengharamkan penyembelihan untuk selain Allah terdapat pada surah alBaqarah 173 dan al-Mâ'idah 3. Memang dalam ayat-ayat tersebut sekalipun yang disebut secara khusus adalah daging babi, namun demikian yang dimaksud adalah seluruh bagian babi, karena dagingnya yang paling besar manfaat dan yang dikehendaki. Kelima, Al-Mawqûdzah, yang berasal dari kata al-wâqidz dengan konotasi sebuah pukulan yang keras. Adat semacam ini sering dilakukan oleh bangsa jahiliah. Mereka memukul binatang ternaknya dengan kayu hingga mati untuk di persembahkan kepada tuhan-tuhan mereka, lalu mereka membuatnya sebagai jamuan. Hewan dipukul dengan batu atau tongkat hingga menyebabkan dia mati tanpa melalui proses penyembelihan. Keenam, Al-Mutaraddiyah, yakni hewan yang terlempar dari tempat yang tinggi sehingga menyebabkan dia mati, baik jatuh dari gunung, sumur, lubang, atau tempat lainnya. Al-Tarada berasal dari kata radda yag berarti binasa. Baik terlempar dengan sendirinya maupun terlempar oleh orang lain. Ketujuh, Al-Natihah, yang berarti sesuatu yang menjadi korban, yaitu hewan yang tertimpa oleh hewan lain dan menyebabkan mati tanpa proses penyembelihan syar'i. Kedelapan, Al-Sabu'u, yaitu hewan yang dimakan oleh binatang buas. Binatang yang bertaring seperti singa atau harimau, atau dimangsa burung yang mempunyai kuku yang panjang dan tajam seperti elang dan garuda. Yang dimaksud di sini adalah hewan yang sebagian anggota tubuhnya sudah dimakan oleh binatang buas. Kesembilan, Al-Nusub/Al-Nasb, yaitu batu yang didirikan di sekitar Ka,bah mereka menyembelih binatang di atas batu tersebut untuk pengorbanan dan pendekatan diri ke pada tuhannya. Sebagian orang menyebutkan bahwa nasb adalah berhala. Konon, bangsa Arab senang menyembelih hewan di Mekah, kemudian menyiramkan darahnya kepada sesuatu yang menghadap Ka'bah. Mereka mengiris dagingnya dan meletakkannya di atas batu, maka ketika Islam datang, orangorang Muslim berkata kepada Nabi Saw, Kami lebih berhak untuk memuliakan Ka,bah ini dengan batu (al-nasb), maka kemudian Allah Swt. menurunkan ayat,Wa mâ dzubih 'ala al-nusub. Dari beberapa ayat di atas dapat disimpulkan bahwa standarisasi makanan halal dalam Islam harus memenuhi tiga kriteria yaitu halal zatnya, halal cara memperolehnya, dan halal cara memproses atau mengolahnya.

Halal secara zat artinya makanan-makanan selain yang secara jelas diatur dalam AlQur'an tentang kriteriannya seperti darah, bangkai, babi, anjing, semua binatang yang mati tidak melalui proses penyembelihan,termasuk binatang yang mati dalam pengangkutan. Bahan dasar makanan tidak boleh mengandung atau tercampur dengan makanan yang diharamkan, bahkan dalam hal penyimpanan makanan halal dan makanan haram secara bersamaan atau berdekatan akan menyebabkan tercemarnya sat halal oleh yang haram. Halal cara memperolehnya artinya makanan harus diperoleh melalui cara-cara yang baik bukan hasil dari perbuatan yang dilarang seperti mencuri, merampok, menipu, ribah, hasil zina dan lainnya.

Halal cara memprosesnya artinya makanan harus diproses, diolah dan disajikan dengan cara-cara yang sesuai dengan standarisasi Islam seperti hewan harus disembelih oleh orang muslim dengan menyebut nama Allah, penyembelihan hewan bukan untuk sesembahan, darah yang keluar dari binatang disembelih harus lancar dan tuntas, dilakukan secara santun dan harus menggunakan pisau yang tajam, daging atau 
bahan tidak boleh tercemar atau tercampur oleh sat haram tercemar bisa melalui bahan baku, bumbu, tercampurnya alat yang digunakan. Alat yang digunakan untuk mengolah makan juga harus terpisah dengan alat pengolahan makanan haram, seperti perabot yang bersih dari zat yang mengandung bahan makanan yang diharamkan, seperti alat masak dan alat saji yang digunakan secara bergantian dengan makanan haram tanpa melalui proses sertu menurut Islam sebagaimana diatur dalam Fatwa MUI No 4 Tahun 2003 bagian ketujuh poin 3. Halal cara memperolehnya artinya makanan atau bahan makanan harus diperoleh melalui cara-cara yang baik karena makanan yang masuk kedalam tubuh manusia akan sangat menentukan kualitas pola pikir serta akal fikiran dan amal ibadah manusia.

\section{SIMPULAN}

Mengkonsumsi makanan halal hukumnya wajib bagi ummat muslim. Wisata halal adalah wujud resposibilitas dunia wisata untuk melindungi kepentingan dan kenyaman ummat muslim untuk berwisata. Geliat wisata halal secara global telah menggiring Indonesia juga untuk menerapkan konsep ini, walaupun secara yuridis baru Provinsi NTB yang telah menindaklanjutinya dengan perda yaitu Perda Provinsi NTB No 2 Tahun 2016 Tentang Parawisata Halal. Praktek wisata halal di NTB semakin meningkat, hal ini dapat dilihat dari peningkatan jumlah wisatawan khususnya wisatawan muslim yang datang berkunjung ke NTB. Namun ada beberapa hal yang masih perlu dibenahi yaitu berkaitan dengan pemurnian konsep wisata halal yang benar-benar sesuai standarisasi syariah, terutama dalam aspek pengolahan makanan dan minuman karena untuk saat ini masih banyak hotel dan restoran di NTB yang belum bersertifikasi halal..

\section{DAFTAR PUSTAKA}

[1] Aan Jaelani, Industri Wisata Halal di Indonesia: Potensi dan prospek, Jurna Fak Syariah dan Ekonomi Islam, IAIN Syeh Nurjati Cirebon, 2017

[2] Abd al-Rahmân ibn Nashir ibn al-Sa'di, Taysîr al-Karîm al-Rahmân fi Tafsîr Kalm alMannân, di-tahqîq oleh 'Abd al-Rahmân ibn Ma'lâ al- Luwayhik, (Mu'assasah alRisâlah, Mâlik Fahd, 1420H-2000H), Cet. I

[3] Imam al-Syawkânî, Fath al-Qâdir, (Bayrût: Dâr al-Ma'rifah, 2007), Cet. IV, hal. 216.

[4] Muhtar Ali, Konsep Makanan Halal dalam Tinjauan Syariah, Ahkam: Vol. XVI, No. 2, Juli 2016

[5] Jaelani, Setyawan, \& Hasyim, 2016, religious heritage tourism and creative economy in cirebon : the diversity of religious, cultures and culinary. Journal of social and administrative sciences

[6] John L. Esposito, Esposito-Hukum, Esposito, John L., Ensiklopedi Oxford Dunia Islam Modern, Penerjemah, Eva YN, dkk, Bandung: Penerbit Mizan, 2001.

[7] Siti Zulaekah dan Yuli Kusumawati, Halal Dan Haram Makanan Dalam Islam, SUHUF, Vol. XVII, No. 01/Mei 2005

[8] Yûsuf al-Qaradhâwî, Al-Halâl wa al-Harâm fi al-Islâm, terjemah Wahid Amadi dkk, Halal Haram dalam Islam, (Solo: Era Intermedia, 1424H-2003 M), Cet III

[9] Departemen Peendidikan Nasional, Kamus Besar Bahasa Indonesia Pusat Bahasa, Jakarta, Gramedia Pustaka Umum, 2008

[10] Adib Bisri dan munawwir AF; kamus Indonesia Arab, Surabaya: Pustaka Progresif, Surabaya, 1999

[11] Suyatno, Ensiklopedi Halal dan Haram dalam Makanan dan Minuman

[12] Abdul Azis Dahlan, et.al, Ensiklopedi Hukum Islam, Jakarta, Ikhtiar Baru van Hoeve, 1996, cet.1

[13] Perda Provinsi NTB Nomor 2 Tahun 2016 tentang Pariwisata Halal 
[14] Peraturan Gubernur Nusa Tenggara Barat Nomor 51 Tahun 2015 tentang Wisata Halal

[15] Fatwa MUI Nomor 4 Tahun 2003 tentang Fatwa Halal

[16] Republika.co.id, Wihdan Hidayat, Stimulan Mempercepat Industri Wisata HalalGeliat Wisata Halal di NTB (bagian 2), 6 April 2016. diunduh pada hari Minggu, 29 Juli 2018, jam 20.00 WITA

[17] http;//www.traveluxion.web.id, Parawisata Indonesia/Halal Taurism, diunduh pada hari Minggu, 29 Juli 2018, jam 20.150 WITA

[18] http://www.kompasiana.com, Melihat Konsep Parawisata Halal, 28 Agustus, 2017, diunduh pada hari Minggu, 29 Juli 2018, jam 21.10 WITA

[19] Surah Al-Maidah ayat 3/tafsirq.com, diunduh pada hari Minggu, 29 Juli 2018, jam 22.00 WITA

[20] Surah Al-Baqorah 172-173/tafsirq.com, diunduh pada hari Minggu, 29 Juli 2018, jam 22.00 WITA 